Semmelweis Egyetem Arc-Állcsont-Szájsebészeti és Fogászati Klinika, Budapest* Óbudai Egyetem Kandó Kálmán Villamosmérnöki Kar*

Dento-Cura Kft. magánrendelő, Budapest**

\title{
Az alsó archarmad Di Paolo-féle vizsgálata Cone-Beam CT adatállományon
}

DR. DOBAI ADRIENN *, DR. VIZKELETY TAMÁS*, MARKELLA ZSOLT**,

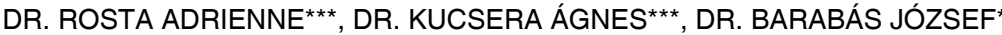

\begin{abstract}
A rekonstruktív sebészet területén gyakran Cone-Beam CT által megvalósítható 3D kefalometria az egyetlen lehetőség a pontos kezelési terv elkészítéséhez. A valódi háromdimenziós normarendszer kidolgozásához első lépésként célul tűztük ki a Di Paolo által leírt analízis 2D vizsgálatát volumentomogrammon és ezt követően 3D adaptációját. 30 Angle I. osztályú okklúzióval rendelkező páciensről készült felvételt válogattunk ki három év alatt azon betegek közül, akikröl nem ortodonciai célból készült CBCT volumentomogram. A vizsgálati csoport tagjairól készült 0,4 $\times 0,4 \times 0,4 \mathrm{~mm}$ voxelméretű volumentomogrammokon a referenciapontokat három vizsgáló, egymástól függetlenül, három alkalommal jelölte ki a Cranio Viewer szoftver segítségével. Meghatároztuk a mandibula és a maxilla vetületi hosszát, szélességét (milliméterben és szögértékben kifejezve), illetve az alsó elülső és hátulsó arcmagasságot. Az anatómiai struktúrák alacsony szórásértékeinek és a közöttük fellépő, nagyrészt szoros korrelációknak köszönhetően a 2D adatállományban megfogalmazott geometriai elképzelés adaptálható a 3D adatállományra, így lehetővé teszi az alsó archarmadot leíró 3D kefalometria létrehozását, amely által a transzverzális aszimmetria is pontosan kiértékelhetővé válik.
\end{abstract}

Kulcsszavak: Cone-Beam CT, kefalometria, malocclusio, Angle I Osztály, anatómiai referenciapont, 3D megjelenítés

\section{Bevezetés}

A kefalometria nemcsak az ortodonciai eltérések diagnosztikájában és a kezeléstervezésben játszik meghatározó szerepet, hanem az arcrekonstrukciós mütétek tervezésében is. A Cone-Beam CT elterjedése lehetővé teszi a koponyaméretek nemcsak kettő, hanem három dimenzióban történő elemzését egy adatállományon, ezáltal lehetőséget biztosítva az esetleges transzverzális irányú arcaszimmetriák vizsgálatára is, melyek a régen használt frontális röntgenképeken a nagyfokú egymásra vetülések miatt nehezen voltak értékelhetőek. A CBCT előnyeinek - a torzítás-, nagyítás- és szummációmentes izometrikus ábrázolásának - köszönhetően a mindennapi diagnosztikában is egyre nagyobb jelentőséggel bír [1]. Legföbb hátránya a relatíve nagy sugárdózis [2-4], mely azonban a technika fejlődésének eredményeként folyamatosan csökken. Azt a tényt figyelembe véve, hogy egy komplexebb ortodonciai kezeléshez egy laterális, egy frontális teleröntgen, egy panorámafelvétel és esetlegesen még további kiegészítő (okklúziós, periapikális) felvételek szükségesek, több vizsgálat is igazolta, hogy e röntgenfelvételek összdózisa gyakran meghaladja a CBCT vizsgálat effektív dózisát [5]. Ennek következtében a nemcsak dentális, hanem szkeletális abnormalitással járó traumás és fejlődési rend- ellenességek diagnosztikája során ma már a CBCT az ajánlott vizsgálati módszer [3, 6]. A fejlesztéseknek köszönhetően, napjainkban már léteznek kifejezetten ortodonciai célokra használható modulok (pl. Planmeca Low-dose), melyek alkalmasak a CBCT rutinszerú alkalmazására a szkeletális eltérések diagnosztikájában és a műtéti tervezések során.

$A z$ archelyreállító mútétek nagy része csak az alsó archarmadot érinti, így az diagnosztikában és kezeléstervezésben kiválóan alkalmazható az 1962-ben Di Paolo által leírt Quadrilaterális analízis, amely az alsó archarmadon mért elülső és hátulsó arcmagasságot, valamint a maxilláris és a mandibuláris alveolus hosszát hasonlítja össze (1. ábra). Ideális arcviszonyoknál 1:1 arány áll fenn a maxilláris alveoláris csontív nyílirányú vetülete és a mandibuláris alveoláris csontív szagittális irányú vetületének hossza között, valamint az elülső alsó arcmagasság [ALFH] és a hátulsó alsó arcmagasság [PLFH] átlaga és az alveoláris csontív-vetületek hossza között.

Azaz Maxilla vetülethossz = Mandibula vetülethossz $=($ Anterior + Poszterior alsó arcmagasság $) / 2$.

Az elülső és hátulsó arcmagasság átlaga az alsó átlagos arcmagasság [LFH]. Ezen kapcsolat figyelembevételével Di Paolo 1969-ben harminckét ortodonciailag kezeletlen, normál okklúzióval rendelkező 10,7-13,6 éves fiatal páciensen, majd 1984-ben már összesen 245 nem- 


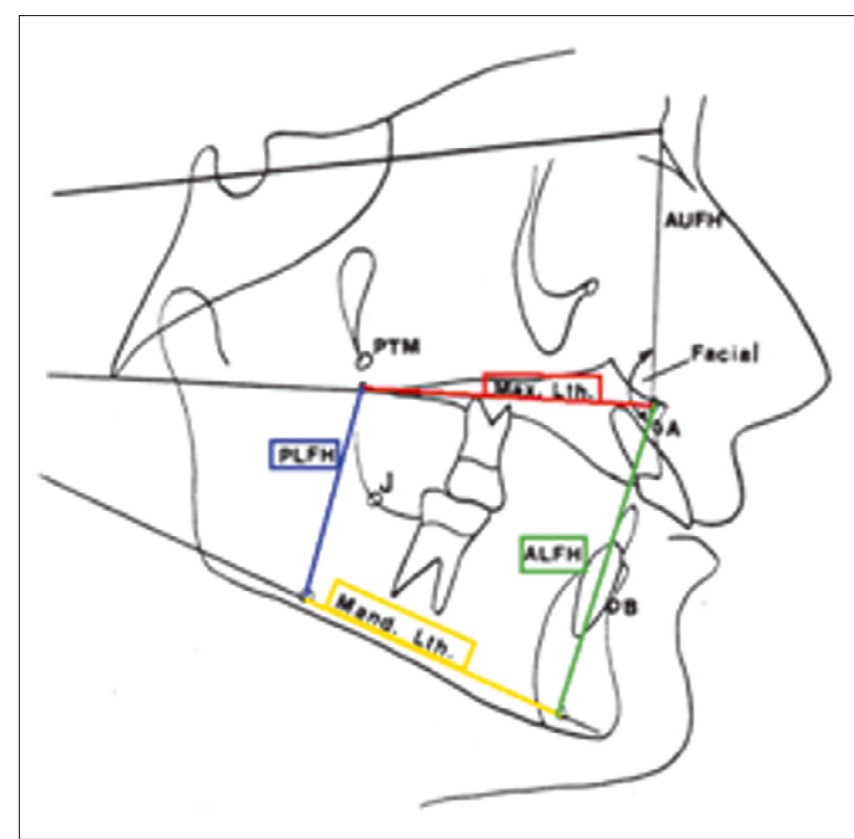

1. ábra: Quadrilaterális analízis:

a maxilláris alveoláris csontív-vetület hossza;

a mandibuláris alveoláris csontív-vetület hossza;

anterior lower facial height [elülső alsó arcmagasság, ALFH]; posterior lower facial height [hátulsó alsó arcmagasság, PLFH]

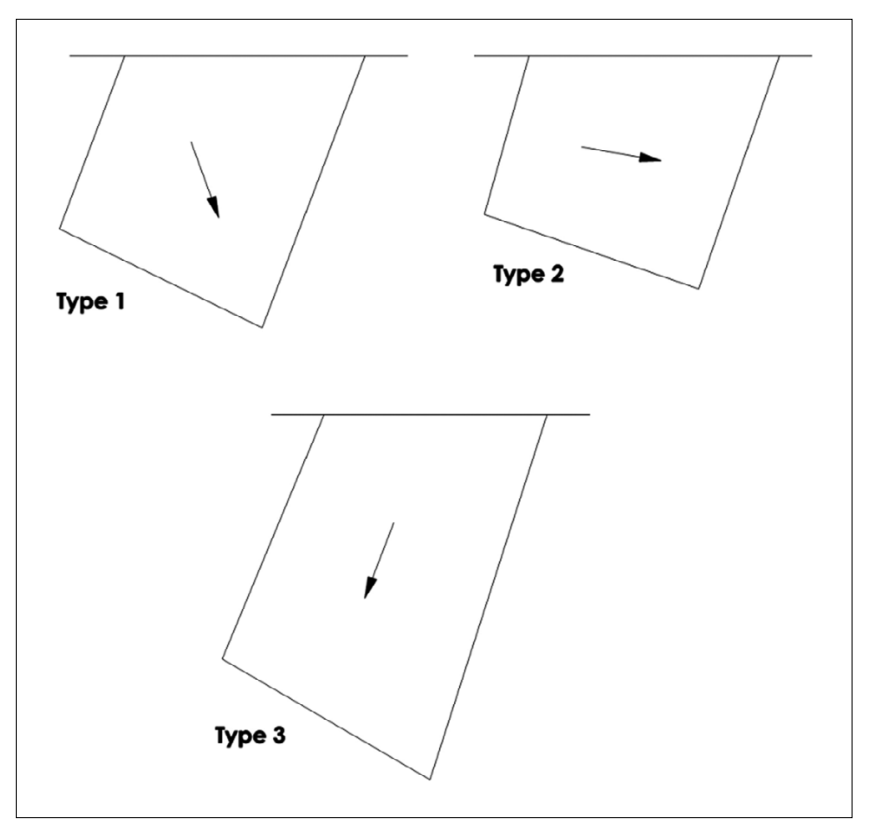

2. ábra: Az alsó arc Di Paolo által meghatározott három növekedési típusa:

Type 1: normodivergens; Type 2: hypodivergens; Type 3: hyperdivergens

[A nyíl jelzi a fő növekedési irányt]

csak normál okklúzióval, hanem hypodivergens és hyperdivergens arctípussal is rendelkező (245 normál-, 64 hypodivergens-, 64 hyperdiverens okklúzió) 9-15 év közötti páciensen (átlagéletkor 12,6) alkalmazta az általa kifejlesztett analízist [7, 8]. A 200 eset vizsgálata során három növekedési mintázatot különített el, a normodivergens, hypodivergens és a hyperdivergens csoportot (2. ábra). A Di Paolo-féle Quadrilateralis analízis a következő előnyökkel rendelkezik a korábban publikált kefalometriai analízisekhez képest:

- Az alsó archarmadra fekteti a hangsúlyt, kiküszöbölve ezzel a koponyaalap lejtéséből eredő „hibás” értékeket.

- Szkeletális rendellenességet vizsgálva alkalmas azon esetek diagnosztikájára is, ahol nem, illetve nem csak dentális eltérés okozza az anatómiai egységek kóros funkcióját.

- A kezelések kivitelezéséhez nagy segítséget nyújt az eltérés milliméterben megadott mértéke, szemben a kefalometriákban általánosan alkalmazott anguláris értékekkel, melyek a gyakorlatban nehezen alkalmazhatók a sebészeti beavatkozások során.

Az ismertetettek alapján vizsgálatunk célja: 1. Az Angle I. osztályú okklúzióval rendelkező csoport tagjain a Di PaoIo-féle quadrilaterális analízis mérőpontjainak validálása az arc-középsíkra vetítve 2D-ben, valamint a kapott lineáris értékek és arányok összevetése az 1984-ben publikált eredményekkel. 2. A 3D adatállomány alapján az alsó archarmadot jellemző hosszértékek szimmetriavizsgálata. 3. A quadrilaterális analízis 3D adaptálása, és a struktúrák közötti korreláció vizsgálata.

\section{Módszer}

Etikai bizottság hozzájárulásával 30 Angle I. osztályú páciensről (18-30 éves) készült CBCT felvételt választottunk ki olyan betegek közül, akikröl nem ortodonciai célú volumentomogram készült a Semmelweis Egyetem Arc-, Állcsont-, Szájsebészeti és Fogászati Klinikáján üzemeltetett i-CAT Classic Cone Beam CT berendezésen. A szelekció során a következő kizáró kritériumokat vettük figyelembe: 1 . Négynél több tömött fog (elsősorban a moláris régióban). 2. Diasthema vagy torlódás. 3. Nagy mértékü $(\geq 1 \mathrm{~cm})$ szkeletális aszimmetria (ennek közelítő becslésére először az I-CAT Vision szoftver segítségével a horizontális segédvonalat a saggitalis képeken Frankfurti horizontálishoz, a coronalis nézetben mindkét orbitabemenet legmélyebb pontjához, a középvonalat a Crista Gallihoz igazítottuk, majd a coronalis CBCT képeken lemértük a középvonaltól az azonos coronalis szeleten lévő két Arcus Zygomaticus, illetve két Processus Coronoideus távolságát. Amennyiben a jobb és bal oldali távolság különbsége nagyobb volt mint $1 \mathrm{~cm}$, akkor a felvételt kizártuk a vizsgálatból. 4. Jelenleg vagy korábban alkalmazott fogszabályozó kezelés. A szkennelést követően középvonali és horizontális vonal pozícióját érintő esetleges korrekciókat az i-CAT Vision szoftver segítségével végeztük el.

A CBCT volumen adatállományból konvertált, DICOM formátumban eltárolt axiális CT szeleteket a Cranio Viewer program axiális, koronális és szagittális nézetben jele- 
níti meg. A szoftver röntgenszerü, CT, MIP (Minimal Intensity Projection), AMIP (Advanced Minimal Intensity Projection) kép, valamint a digitalizált pontokból létrehozott vonalábra megjelenítésére képes (3. ábra). A 0,4 $\times 0,4 \times 0,4 \mathrm{~mm}$ voxelméretű volumentomogrammokon a referenciapontokat három vizsgáló (2 fogorvos és egy radiológus) egymástól függetlenül három alkalommal jelölte be egyhetes intervallumokkal. Miután több tanulmány is igazolta, hogy a pontok definíciói meghatározzák a referenciapontok azonosíthatóságát, így a kutatásunkhoz szükséges kefalometriai pontok helyét mindhárom sík figyelembevételével definiáltuk [9-11]. A vizsgálók egyformán sajátították el a Cranio Viewer szoftver használatát, és közel megegyező tapasztalattal rendelkeztek, ezzel kiküszöbölve az eltérő gyakorlati szint okozta hatásokat a pontok azonosíthatóságára. A 2D-s elemzésnél a pontok középsíkra vetítése során határoztuk meg a hosszakat, míg 3D-ban már a pontok valódi, térbeli helyzetét vettük figyelembe annak érdekében, hogy elkerüljük az analóg teleröntgen torzításából származó hibákat, valamint lehetővé tegyük az aszimmetria kiértékelését.

A 2D vizsgálatban a középsíkra vetítettük a Spina Nasalis Anteriort (SNA), Spina Nasalis Posteriort (SNP), az A-pontot és a két Pterygomaxillare, majd az SNA és SNP által alkotott maxilláris alapvonalra állítottunk merőlegest az A-pontból, illetve a kétoldali Pterygomaxillarek átlagából. A Gonion-Gnathion által létrehozott mandibuláris alapot szintén a középsíkra vetítettük, majd a középsíkra vetített B-pontot és a J-pontból álítottunk rá merőlegest (1. ábra).

A 3D vizsgálatban a maxilláris síkot a SNA és SNP magasságában mért kétoldali Ptergomaxillare által definiáltuk, majd erre vetítettük rá az A pontot és a Pterygomaxillararékat. A mandibuláris síkot a kétoldali Gonion és Gnathion határozta meg, és a kétoldali J-pontokat és a B-pontot vetítettük rá. Ennek következtében a maxilla hosszát, a mandibula hosszát, az elülső és hátulsó arcmagasságon túl a mandibula és maxilla szélességét is sikerült meghatározni (3. ábra).

Leíró statisztikai elemzések során meghatároztuk a középsíkra vetített kétdimenziós vetületi hosszértékek átlagát, szórását, valamint egymintás t-próba által összevetettük az értékeket a korábban publikált eredményekkel. A 3D vizsgálat során az aszimmetriát a kétoldali lineá-

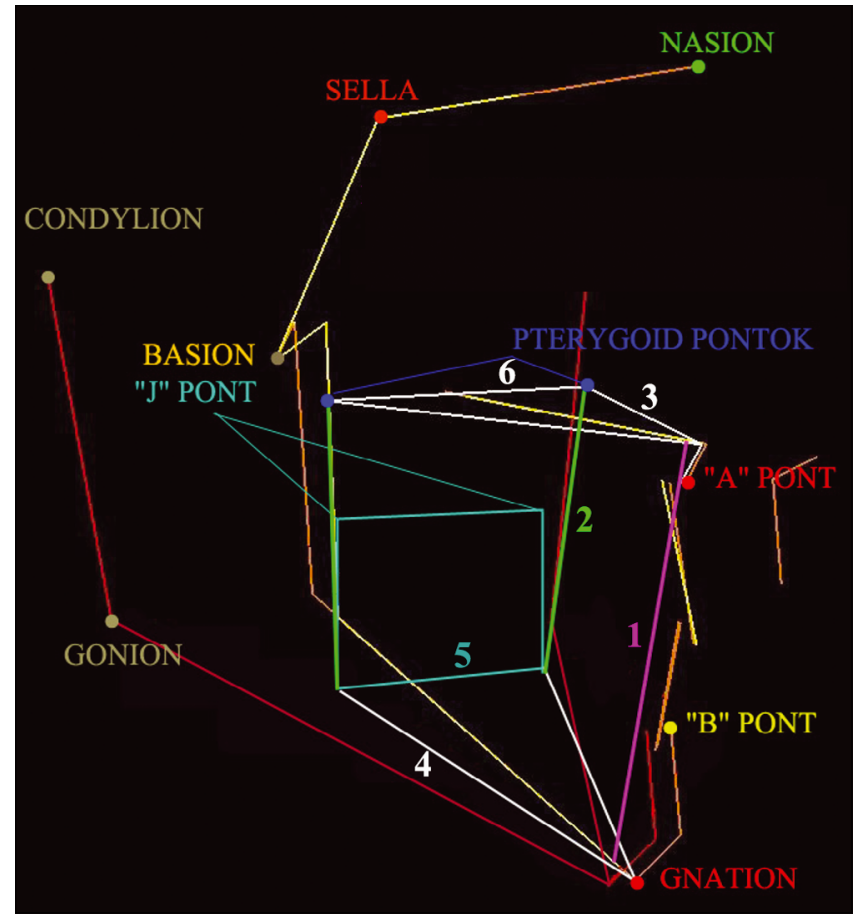

3. ábra: A Quadrilaterális analízis három dimenzióban alkotott képe a Cranio Viewer segítségével.

(1. Elülső alsó arcmagasság [ALFH];

2. Hátulsó alsó arcmagasság [PLFH]; 3. Maxilla hossz;

4. Mandibula hossz; 5. Mandibula szélesség; 6. Maxilla szélesség)

ris értékekből számolt párosított t-próba segítségével elemeztük, valamint a Quadrilaterális analízis referenciavonalait kibővítettük a maxilla és mandibula szélességgel, és minden anatómiai struktúra esetében meghatároztuk az átlagot és a szórást. Az egyes struktúrák között fellépő függőséget korrelációelemzéssel azonosítottuk annak reményében, hogy az egymást befolyásoló erős hatásoknak köszönhetően a jövőben egyenlettel írhatjuk le az alsó archarmad alkotóelemeinek arányát.

\section{Eredmény}

\section{Dimenzió}

A középsíkra vetített értékeknél (I. táblázat) a maxilla vetületi hossz ( $p=0,02)$, a mandibula vetületi hossz $(p=0,016)$, ALFH $(p=0,00), \operatorname{PLFH}(p=0,00)$, LFH

Di Paolo és az általunk két dimenzióban meghatározott hosszértékek átlaga és szórása

\begin{tabular}{|l|c|c|c|c|}
\hline & $\begin{array}{c}\text { Átlag [mm] } \\
\text { Di Paolo Normodivergens csoport }\end{array}$ & SD [mm] & $\begin{array}{c}\text { Átlag [mm] } \\
\text { 2D Normodivergens csoport }\end{array}$ & SD [mm] \\
\hline Maxilla & 50,9 & 2,0 & 51,81 & 2,66 \\
\hline Mandibula & 50,0 & 2,5 & 50,87 & 3,36 \\
\hline ALFH & 60,0 & 3,5 & 63,93 & 5,20 \\
\hline PLFH & 39,4 & 2,2 & 45,29 & 4,08 \\
\hline LFH & 49,7 & 2,8 & 54,59 & 4,18 \\
\hline
\end{tabular}


Az egyes növekedési mintának megfelelő arányok

\begin{tabular}{|l|c|c|c|c|}
\hline \multirow{2}{*}{ Arányok } & \multicolumn{3}{|c|}{ Di Paolo-féle eredmények } & Eredmények \\
& \multicolumn{3}{|c|}{$\mathbf{1 9 8 4}$} & $\mathbf{2 0 1 2}$ \\
\cline { 2 - 5 } & Normodivergens & Hypodivergens & Hyperdivergens & Normodivergens \\
\hline Max./Mand & $1 / 0,99$ & $1 / 0,98$ & $1 / 1,01$ & $1 / 0,98$ \\
\hline Max./LFH & $1 / 0,99$ & $1 / 0,88$ & $1 / 1,15$ & $1 / 1,05$ \\
\hline PLFH/ALFH & $1 / 1,52$ & $1 / 1,46$ & $1 / 1,66$ & $1 / 1,41$ \\
\hline
\end{tabular}

( $p=0,00$ ) szignifikánsan különbözött az 1984. évi eredményektől. A szórások 2,66 és 5,20 mm között voltak, a legnagyobb standard deviációval mind a jelenlegi, mind a korábbi vizsgálatban az ALFH (elülső alsó arcmagasság) rendelkezett, azonban ez a korábban publikált 3,5 mm-ről 5,20 mm-re növekedett. A középsíkból számolt adatok alapján a kapott arányokat a Il. táblázat tartalmazza. Egy kivételtől eltekintve szignifikáns különbség volt a jelen kutatás eredményei és a korábban publikált hypo-, hyper és normodivergens arányok között. A max./mand arány esetében közel azonos volt a viszonyszám az általunk mért Angle I-es és a Di Paolo által vizsgált hypodivergens csoport esetében.

\section{III. táblázat}

A háromdimenziós mérések során kapott hossz, szélesség és szögértékek

\begin{tabular}{|l|c|c|}
\hline & Átlag & SD \\
\hline Maxilla jobb [mm] & 56,94 & 3,07 \\
\hline Maxilla bal [mm] & 56,83 & 3,07 \\
\hline Mandibula jobb [mm] & 61,01 & 4,30 \\
\hline Mandibula bal [mm] & 60,75 & 3,84 \\
\hline ALFH [mm] & 64,02 & 5,60 \\
\hline PLFH jobb [mm] & 46,77 & 4,21 \\
\hline PLFH bal [mm] & 46,46 & 4,06 \\
\hline LFH jobb [mm] & 55,40 & 4,35 \\
\hline LFH bal [mm] & 55,19 & 4,23 \\
\hline Poszterior Maxilla szélesség [mm] & 45,75 & 3,48 \\
\hline Poszterior Mandibula szélesség [mm] & 67,07 & 4,64 \\
\hline Maxilla szög [fok] & 47,03 & 2,99 \\
\hline Mandibula szög [fok] & 66,84 & 4,17 \\
\hline
\end{tabular}

\section{Dimenzió}

A háromdimenziós eredményeket tekintve nem volt szignifikáns eltérés a kétoldali mérések között $(p \geq 0,05)$ (III. táblázat), ugyanakkor a háromdimenziós hosszértékek szignifikánsan eltértek a középsíkra vetített kétdimenziós adatoktól.

A Di Paolo analízis mindhárom síkra történő kiterjesztése során meghatározott hossz és szélességértékek közötti korrelációkat a IV. táblázat mutatja, melyből jól látható, hogy struktúrák között releváns és szignifikáns kapcsolat áll fenn $(r=(-0,254)-(+0,917))$, kivéve a maxilla és mandibula szélességet leíró szögeket, melyeknél a korrelációs együttható értéke -0,2 és +0,2 között helyezkedett el, vagy $p>0,05$.

\section{Megbeszélés}

Bár az első kefalogram elkészítésével megjelentek az újabbnál újabb koponyamérési analízisek, 1984-ig mégsem volt egy sem, ami kizárólag az alsó archarmad leírását tűzte volna ki célul, valamint az anguláris értékelés helyett lineáris modellt alkalmazott volna.

A Quadrilaterális elemzés jelentősége abban rejlik, hogy nem veszi figyelembe a Sella és Nasion által leírt elülső koponyaalapot az alsó archarmad vizsgálata során. Ennek az a magyarázata, hogy a hagyományos kefalometriában leggyakrabban alkalmazott ANB-szög és az ezen alapuló antero-poszterior viszonyok leírása számos esetben hibás következtetést vonhat maga után. Így például a fejlődési rendellenességekből származó kóros vertikális és horizontális Nasion/Sella helyzetek, alsó archarmad komplexus rotációk, valamint a traumás sérülésekből adódó Nasion sérülések, diszlokációk mind téves értékekhez vezethetnek.

Di Paolo-t megelőzve, bár születtek próbálkozások e probléma megoldására, mint például a WITS analízis [12], mely az alsó archarmadban maradva írja le az állcsontok között található antero-poszterior eltéréseket az A- és B-pontnak az okklúziós síkra való merőleges rávetítésével, azonban nem határozza meg sem a „kóros” állcsontot, sem azt, hogy az antero-poszterior irányban létrejött diszkrepanciáért az eltérő állcsont pozíciója, vagy mérete-e a felelős.

A Quadrilaterális analízis a dentoalveoláris viszonyoktól függetlenül az alsó archarmad szkeletális komplexusával foglalkozó analízis, mely előre jelzi a páciens növekedési mintáját, meghatározza a rendellenesség pontos lokalizációját, így segítséget nyújt individuális kezelési terv elkészítésében [7, 8, 13-15].

A középvonali síkra vetített $2 \mathrm{D}$ elemzés, az eredeti $2 \mathrm{D}$ hosszértékek, valamint az aránypárok között szignifikáns különbség figyelhető meg, ami több faktor befolyásoló hatására vezethető vissza:

- Vizsgálati csoport: Az etnikumból adódó anatómiai eltérések, valamint a beválasztási kritériumok kisfokú eltérése is befolyásoló tényezőként lép fel. A Di Paolo által végzett analízisben az anatómiai struktúrák méretének átlaga nagyobb volt, mint az általunk végzett kutatásban, melynek hátterében az egyes vizsgálati csoportok életkorai közötti eltérés állhat. (Di Paolo-féle vizsgálat 1984, átlagéletkor: 12,6; jelen vizsgálat, átlagéletkor: 25) [8]. Mindezek mellett 
Az alsó arcot felépítő anatómiai képletek közötti korrelációs együtthatók

\begin{tabular}{|c|c|c|c|c|c|c|c|c|c|}
\hline & $\begin{array}{c}\text { Maxilla } \\
\text { jobb }\end{array}$ & $\begin{array}{c}\text { Mandibula } \\
\text { jobb }\end{array}$ & ALFH & $\begin{array}{l}\text { PLFH } \\
\text { jobb }\end{array}$ & $\begin{array}{l}\text { LFH } \\
\text { jobb }\end{array}$ & $\begin{array}{l}\text { Poszterior } \\
\text { maxilla } \\
\text { szélesség }\end{array}$ & $\begin{array}{c}\text { Poszterior } \\
\text { mandibula } \\
\text { szélesség }\end{array}$ & $\begin{array}{c}\text { Maxilla } \\
\text { szög }\end{array}$ & $\begin{array}{c}\text { Mandibula } \\
\text { szög }\end{array}$ \\
\hline Maxilla jobb & 1 & $0,710^{* *}$ & $0,566^{\star *}$ & $0,434^{* *}$ & $0,575^{\star *}$ & $0,522^{\star \star}$ & $0,381^{\star *}$ & 0,094 & $0,411^{\star *}$ \\
\hline Mandibula jobb & & 1 & $0,504^{\star *}$ & $0,356^{\star *}$ & $0,497^{* *}$ & $0,478^{\star \star}$ & $0,679^{\star \star}$ & 0,074 & $0,394^{\star *}$ \\
\hline ALFH & & & 1 & $0,564^{\star *}$ & $0,917^{\star *}$ & $0,406^{\star \star}$ & $0,300^{\star *}$ & 0,022 & $0,254^{*}$ \\
\hline PLFH jobb & & & & 1 & $0,847^{\star \star}$ & $0,271^{\star \star}$ & $0,388^{\star \star}$ & 0,072 & 0,025 \\
\hline LFH jobb & & & & & 1 & $0,393^{\star *}$ & $0,381^{\star \star}$ & 0,049 & 0,152 \\
\hline $\begin{array}{l}\text { Poszterior maxilla } \\
\text { szélesség }\end{array}$ & & & & & & 1 & $0,454^{\star \star}$ & $0,644^{\star \star}$ & 0,015 \\
\hline $\begin{array}{l}\text { Poszterior mandibula } \\
\text { szélesség }\end{array}$ & & & & & & & 1 & $0,255^{\star}$ & $0,389^{* *}$ \\
\hline Maxilla szög & & & & & & & & 1 & $0,284^{\star \star}$ \\
\hline Mandibula szög & & & & & & & & & 1 \\
\hline
\end{tabular}

* $0,01 \%$-os szignifikancia szint; ${ }^{* *} 0,05 \%$-os szignifikancia szint

nem elhanyagolhatók a minták eltérő elemszámai sem (Di Paolo: $n=245$, jelen vizsgálat $n=30$ random okklúzióval rendelkező páciens), melyek elsősorban a szórásértékeket befolyásolják [8].

- Mérési módszer: Röntgenfelvétel során fellépő torzítás és nagyítás, valamint a pauszpapíron végzett mérés pontossága jóval kisebb, mint a CBCT segítségével készült 3D adatbázison a Cranio Viewer számítógépes programmal végzett digitalizálás [1]. Ennek következtében a korábban kettő dimenzióban létrehozott referenciaértékek nem alkalmazhatók a három dimenzióban, volumentomogrammon végzett mérések során.

A három dimenzióban végzett vizsgálat során kiderült, hogy az alsó archarmadot meghatározó maxilla, mandibula és hátulsó arcmagasság hosszértékei közel azonos értékủek, így kétoldali szimmetriával jellemezhetők. A tér minden irányába kiterjesztett analízis nemcsak a maxilla, mandibula és az arcmagasságok hosszát, hanem az állcsontok szélességét is jellemzi. A különböző anatómiai struktúrák között fellépő korrelációt kihasználva könnyen meghatározható, hogy normál okklúzió - ami a helyreállító mútétek legfőbb célja - esetében például egy adott maxilla hosszértékhez milyen mandibula hossz- és szélességértékek, valamint alsó archarmad mely magasságértékei tartoznak. Mindezek tudatában könnyen és precízen végezhető el az ortodonciai és rekonstruktív kezelés megtervezése.

\section{Következtetés}

Az alsó archarmad szkeletális vizsgálata során a Di Paolo-féle analízis háromdimenziós kiterjesztése lehetőséget ad az eltérés minden irányban történő lokalizációjának, illetve mértékének meghatározására. A tényleges mérhető transzverzális értékek tovább pontosítják az analízist, valamint lehetővé teszik az alsó archarmad aszimmetria-vizsgálatát is.

\section{Irodalom}

1. Uintero JC, Trosien A, Hatcher D, Kapila S: Craniofacial imaging in orthodontics: historical perspective, current status, and future developments. The Angle orthodontist. 1999; 69: 491-506.

2. Chau AC, Fung K: Comparison of radiation dose for implant imaging using conventional spiral tomography, computed tomography, and cone-beam computed tomography. Oral surgery, oral medicine, oral pathology, oral radiology, and endodontics. 2009; 107: 559-565.

3. De Vos W, Casselman J, Swennen GR: Cone-beam computerized tomography $(\mathrm{CBCT})$ imaging of the oral and maxillofacial region: a systematic review of the literature. International journal of oral and maxillofacial surgery. 2009; 38: 609-625.

4. Silva MA, Wolf U, Heinicke F, Bumann A, Visser H, Hirsch E: Cone-beam computed tomography for routine orthodontic treatment planning: a radiation dose evaluation. American journal of orthodontics and dentofacial orthopedics: official publication of the American Association of Orthodontists, its constituent societies, and the American Board of Orthodontics. 2008; 133: 640. e1-5.

5. Zamora N, Llamas JM, Cibrian R, Gandia JL, Paredes V: A study on the reproducibility of cephalometric landmarks when undertaking a three-dimensional (3D) cephalometric analysis. Medicina oral, patologia oral y cirugia bucal. 2012; 17: e678-688.

6. Cattaneo PM, Melsen B: The use of cone-beam computed tomography in an orthodontic department in between research and daily clinic. World journal of orthodontics. 2008; 9: 269-282.

7. DI PAOLO RJ: The Quadrilateral Analysis. J Pract Orthodontics. 1969; 523-530.

8. Di PaOlo RJ PC, Maganzini AL, HiRCE JD: The quadrilateral analysis: A differential diagnosis for surgical orthodontics. Am J Orthod 1984; 86: 470-482.

9. FL B: Morphometric Tools for Landmark Data. Cambrige University Press, 1991, 453.

10. Lou L, Lagravere MO, Compton S, Major PW, Flores-Mir C: Accuracy of measurements and reliability of landmark identification with computed tomography (CT) techniques in the maxillofacial area: a systematic review. Oral surgery, oral medicine, oral pathology, oral radiology, and endodontics. 2007; 104: 402411.

11. Major PW, Johnson DE, Hesse KL, Glover KE: Landmark identification error in posterior anterior cephalometrics. The Angle orthodontist. 1994; 64: 447-454.

12. JaCOBSON A: Application of the "Wits" appraisal. Am J Orthod. 1976; 179-189. 
13. CHINAPPI A: A quadrilateral analysis of lower face skeletal patterns. Am J Orthod. 1970; 341-350.

14. Di Paolo RJ MJ, Castaldo DA: Cephalometric Diagnosis Using the Quadrilateral Analysis. J Clin Orthod 1970; 4: 30-35.
15. Di Paolo RJ PC, Maganzini AL, HiRCE JD: The quadrilateral analysis: An idividualized skeletal assessment. Am J Orthod 1983; 83: $19-32$.

Dobai A, Vizkelety T, Markella Zs, Kucsera Á, Rosta A, Barabás J

\section{Di Paolo's cephalometrical analysis of lower face by means of Cone-Beam CT}

Object: 3D cephalometry is often the only way to set up accurate diagnosis and treatment plan in the field of reconstructive surgery. In these cases complement exposures are needed beyond common cephalograms with higher accuracy than conventional Cone-Beam CT. Consequently the aim of our study was to perform a complex 3D cephalometry. As the first step of this approach, was the 3D adaptation of DiPaolo's Quadrilateral technique, and to determine norms of references in lower face by means of CBCT. Method: Thirty non-orthodontic CBCT scans were selected for the digitalization. The most important inclusion criteria was Class I occlusion. Locations of 55 landmarks were signed three times by three observers by means of Cranio Viewer software. Results: However Quadrilateral analysis contains only millimetric values we also integrate angles in the $3 \mathrm{D}$ version to determine the width of maxilla and mandible. In the $2 \mathrm{D}$ examination - where landmarks were projected to the middle plane. The SDs of the lengths were between 2,66 $\mathrm{mm}$ and 5,20 mm. The ratios of normodivergent lower face were significant different from the one by DiPaolo. In 3D adaptation there were no significant differences between the measurements of the two sides $(p \geq 0,05)$. We found mostly strong and significant correlations between each anatomical structure except of angles. Conclusion: Creation of 3D Quadrilateral cephalometry by means of strong correlation and norms of Class I occlusion provide a practical, reliable method to measure also the transversal asymmetry of lower face which is necessary part of 3D cephalometry.

Keywords: Cone-Beam Computed Tomography, cephalometry, Malocclusion, Anatomic Landmarks, Three-Dimensional Imaging 